\title{
Molecular studies on African swine fever virus from Brazilian isolates
}

\section{Estudos moleculares do vírus da peste suína africana de isolados brasileiros}

\author{
Tânia Rosária Pereira Freitas ', Tânia Maria de Paula Lyra*
}

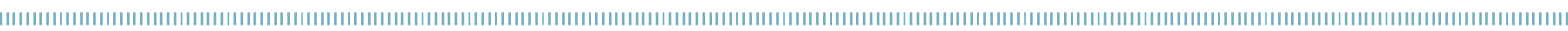

\begin{abstract}
African swine fever (ASF) is a devastating viral infirmity that affects domestic and wild swine caused by the ASF virus (ASFV) that belongs to the family Asfaviridae in the Asfavirus genus. Studies for genotypic and antigenic determination of ASFV including samples from Brazilian outbreaks were carried out outside Brazil. Here, we have reviewed studies on the molecular aspects of Brazilian isolates from 1978 and 1979. Results obtained from restriction fragment analysis, cloning and gene sequencing display the genotypic variation of viral samples. Viral genotyping based on sequences of the 3' region of the p72 gene included in genotype I Brazilian samples, reinforcing the suggestion of the European origin for the virus that infected Brazilian herds and having low virulence potential. Corroborating those findings, at the American station PIADC, the infection of healthy pigs with the Brazilian strain induced ASF sub acute disease with low mortality and a low-virulence. Those results were similar with epidemiological vigilance forms of Brazilian swineherd in good health conditions having at least one ASFV isolation, and the ASF pioneer's studies on the low mortality in the Brazilian herds affected by ASF. The ASFV spreading in Eastern Europe and Russia triggered a greater concern with intensifying the risk of viral dissemination from country to country. The low virulence ASF strains can increase the problem because of hidden viral reservoirs - which further reinforces the need for safety and preventive measures in virus-free countries. Finally, the problem is further compounded by the lack of vaccines and other immunological resources.
\end{abstract}

KEYWORDS: african swine fever virus; genotyping; virulence.
RESUMO: A peste suína africana é uma enfermidade viral devastadora que afeta suínos domésticos e selvagens causada pelo vírus pertencente à família Asfaviridae no gênero Asfavirus. Estudos para determinação genotípica e antigênica do vírus da peste suína africana, incluindo as amostras de surtos brasileiros, foram realizados em laboratórios fora do Brasil. Aqui, revisamos os estudos sobre o aspecto molecular de isolados brasileiros de 1978 e 1979. Os resultados obtidos pela análise de fragmentos de restrição, clonagem e sequenciamento mostram variação genotípica das amostras virais. A genotipagem viral baseada nas sequências da regiáo 3' do gene p72 incluíram amostras brasileiras no genótipo I, reforçando a sugestão da origem europeia do vírus que infectou rebanhos brasileiros e potencialmente de baixa virulência. Corroborando, na estação americana Plum Island Animal Disease Center, a inoculação do vírus da peste suína africana do surtos brasileiros em suínos saudáveis evoluiu para peste suína africana subaguda com baixa mortalidade sugerindo a baixa virulência. Similarmente aos formulários de vigilância epidemiológica de rebanhos em boas condiçóes sanitárias que tiveram pelo menos um isolamento de vírus da peste suína africana e com os estudos pioneiros sobre a baixa mortalidade nos rebanhos afetados pela peste suína africana. A dispersão do vírus da peste suína africana na Europa Oriental e Rússia desencadearam uma preocupaçáo com o risco de disseminação do vírus entre países. $\mathrm{O}$ vírus da peste suína africana de baixa virulência pode aumentar o problema porque esconde reservatórios virais e reforça a necessidade de medidas preventivas e de segurança em países livres de vírus. Finalmente, o problema é ainda mais agravado pela falta de vacinas e outros recursos imunológicos.

PALAVRAS-CHAVE: vírus da peste suína africana; genotipagem; virulência. 
African swine fever (ASF) is a devastating viral infirmity that affects domestic and wild swine animals. In domestic swine, aggressive strains of the virus cause an acute form of ASF associated with hemorrhagic lesions and $100 \%$ mortality rates within 8 to 12 days of infection (MCDANIEL, 1981). Subacute and chronic forms of ASF result from strains of low to moderate virulence, in which cases the animals can propagate the virus for six or more months (COSTARD et al., 2009).

Pig farms affected by ASF suffer enormous economic losses due to sanitary problems and disease eradication which, as recommended by international guidelines, requires the elimination of infected animals and animals that could have been exposed to the disease. Moreover, the property should undergo a quarantine during which animal commerce must cease (LYRA, 2006; COSTARD et al., 2009). Since 2007, ASF outbreaks in European and Russian domestic swine populations and the number of ASF cases among wild boars has dramatically increased. The situation warrants extensive investigation of viral strain characteristics (GUINAT et al., 2016).

The etiological agent of the disease is named ASF virus (ASFV) and was initially classified in the Iridoviridae family due to structural similarities to other members of the family and to the cytoplasmic localization of the viral genome. However, genomic structure, replication strategy, and the existence of viral enzymes that participate in the initial processes of viral particle replication more closely resemble members of the Poxviridae family of viruses. Currently, the ASFV represents the only member of the Asfivirus genus and the Asfaviridae family - African Swine Fever Virus (BASTOS et al., 2003).

Spherical virions or integral viral particles have a diameter of 175 to $215 \mathrm{~nm}$ and include a genomic center consisting of a nucleoprotein structure or complex named nucleoid, measuring from 70 to $100 \mathrm{~nm}$ in diameter. This central structure is protected by an icosahedral protein capsid $(\mathrm{T}=189-217)$ ranging between 172 and $191 \mathrm{~nm}$ in diameter and displaying a hexagonal appearance. Each capsid includes 1,892 to 2,172 capsomeres, the matrix protein, and an outer lipid envelope (Fig. 1).

The first completely sequenced ASFV genome (YANEZ et al., 1995) belonged to a non-virulent strain named BA71V originated from a Spanish sample adapted to Vero cell cultures (ENJUANES et al., 1976). The strain had the following physicochemical characteristics: sedimentation coefficient of 60S; 58-mm circumference; $41 \%$ G-C content; and molecular weight of $102 \mathrm{MD}$ (ENJUANES et al., 1976).

The ASFV genome consists of a double-stranded linear DNA molecule, rich in A-T residues. The size of the DNA molecule varies between 170 and 193 kilobase pairs (kbps) depending on the isolate, and contains hairpin loops (HPL) as well as inverted terminal repeats (ITRs). Genomic DNA of the BA71V strain has $170 \mathrm{kbps}$ in length. PCR amplification of the 3' end of the $p 72$ gene (478 bps) followed by DNA sequencing and phylogenetic analysis allowed the classification of ASFV in ten major groups. The Brazilian strain was included in the largest and most homogeneous p72 genotype, genotype 1, also referred to as the ESACWA genotype, which also comprised viruses from Europe, South America, the Caribbean and West Africa (BASTO et al. 2003). CHAPMAN et al. (2008) compared the size of the genomic DNA in virulent and non-virulent strains of the genotype 1 group with BA71V. The authors showed that the unique DNA coding sequences of the viral genome, excluding HPL and ITR regions, were smaller in the non-virulent BA71V $(165,795$ bps) and Portuguese (171,701 bps) strains than in virulent strains such as the African Benin 97/1 (180,971 bps).

Genes are coded in both DNA strands (SALAS; ANDRÉS, 2013). Small tandem repeats (STRs) arranged in a head-to-tail manner were observed in several intergenic regions. The complex genome contains between 150 and 167 open reading frames (ORFs), which lie close together. These areas can be read in both DNA strands, and code for 100 to 200 proteins, of which around 50 are incorporated in the viral particle (SALAS; ANDRÉS, 2013).

The ASFV genome contains a central preserved region of approximately $125 \mathrm{kbps}$, although several tandem repeat sequences (TRS) were found in this region (GALLARDO et al., 2009). The largest variable extensions of the ASFV genome occur in both ends of the double-stranded DNA. These ITRs occur in a 46-kbp segment on the 5' terminus and in a 12.5-kbp segment on the 3' terminus (YANEZ et al., 1995). Figure 2 summarizes this information in a simplified scheme of the ASFV genome based on the BA71V strain.

The complete genome sequencing of strain $B A 71 \mathrm{~V}$ revealed 151 main ORFs coding for at least 90 proteins involved in intracellular viral replication. The complex viral particle consists of more than 50 proteins, including those with structural function and packaging enzymes. Nevertheless, more than 100 proteins induced by the virus have been identified in infected Vero cells (ALCAMI et al., 1992; SALAS; ANDRÉS, 2013). The viral genome also includes two genes associated

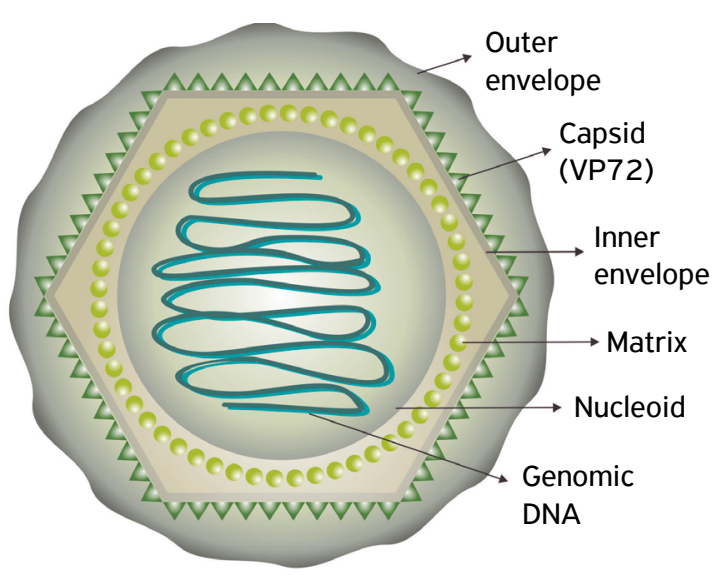

Freitas; Tavares 2016

Figure 1. Schematic composition and structure of the African swine fever virus. Adapted from SALAS; ANDRÉS (2013). 
with polyprotein precursors, which are processed into two or four viral proteins (ANDRÉS et al., 1997). At least five multigene families (MGF) were identified on the 5' and 3' variable regions of the genomic DNA (ITR, Fig. 2) and named MGF100, MGF110, MGF300, MGF360 and MGF505/530. Mutations in these regions lead to MGF insertions or deletions and have an association with the virulence of different isolates (AFONSO et al., 2004. BURRAGE et al., 2004; CHAPMAN et al., 2008). The smaller size of non-virulent strain genomes may result from large deletions, especially in the MGF300 and 550/530 regions (CHAPMAN et al., 2008; NEILAN et al., 2002; TULMAN; ROCK, 2001).

ASFV undergoes nucleocytoplasmic replication in infected cells, suggesting a possible common ancestor with superfamily nucleocytoplasmic large DNA viruses (NLDV) (DIXON et al., 2013). Intracellular viral morphogenesis occurs in perinuclear regions in which a cluster of particles named "virus factory" forms from the endothelial reticulum (ROUILLER et al., 1998). The main capsid protein p 72 accounts for $35 \%$ of the viral mass. Structural proteins, including p150, p37, p34 and p14, derived from polyprotein p220 represent 25\% of the mass (ANDRÉS et al., 1997).

The ASFV infects cells of the phagocytic mononuclear system, including fixed macrophages from specific tissue lineages such as reticular cells from the spleen, lymph nodes, lungs, kidneys and liver. Their viral ability to infect these cells represents a key virulence factor. Whereas virulent strains can trigger extensive necrosis of infected tissues, strains with low virulence may infect tissues causing less severe damage (MCDANIEL, 1981; MEBUS et al., 1981; CARRILLO et al., 1994; AFONSO et al., 2004).

In the laboratory, ASFV can be propagated in primary monocyte cultures - macrophages obtained from swine blood by hemadsorption (HAD) (FREITAS et al., 2015). New cell lineages such as COS.1 and other swine lineages, including Immortalized porcine alvolar macrophages (IPAM) and Wildboard Lung cells (WSL), have been successfully employed for viral propagation (LEÓN et al., 2013).

The broad diversity of antigens poses an obstacle for the development of an ASFV vaccine. An animal that survives ASFV infection produces antibodies that effectively neutralize

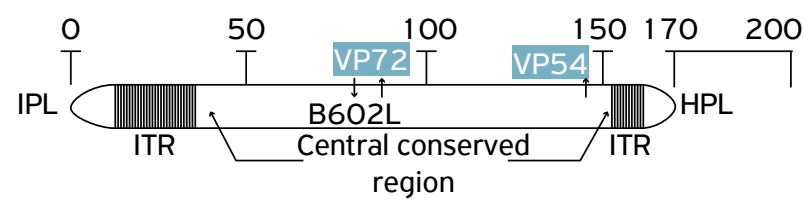

Freitas; Tavares 2016

Figure 2. Simplified scheme of the African swine fever virus genome based on the sequence of the non-pathogenic BA7 1 V strain (YANES et al., 1995). The scheme indicates the location of genes that code for vp72 and vp54 proteins and the B602L gene. Number indicate kilobase pairs (kbp). Adapted from YANES et al. (1995). other viruses of the same group, i.e., homologous viruses. However, these antibodies confer no protection against heterologous viruses (MEBUS et al., 1981; HAMDY; DARDIRI, 1984; MALOGOLOVKIN et al., 2015). A few studies have indicated that capsid protein p72 (VP72) triggers a neutralizing humoral immune response. The protein is antigenically stable and has epitopes which remain preserved in diverging strains (DIXON et al., 2013). Small variations in the nucleotide sequence of the $p 72$ gene allowed the use of this segment in AFSV genotyping (BASTOS et al., 2003; NIX et al., 2006).

The AFSV can infect Ornithodorus sp., soft ticks of the Argasidae family, and remain the sole arbovirus with a DNA genome (THOMSON et al., 1981). The tick viral cycle contributes to disease propagation in the wild. For example, the virus cycles between wild African pigs, Phacochoerus and Potamochoerus spp., and soft ticks of the "moubata complex", in particular Ornithodorus moubata (DIXON; WILKISON, 1988). During an ASF outbreak in Portugal, the virus was detected in ticks of the $O$. erraticus species (BASTO et al., 2006; GALLARDO et al., 2011).

Several lines of research initiated in the last century mainly in the USA, Spain and England - applied molecular methods to investigate ASFV genotypes and antigens. In addition to characterizing the virus, these efforts aimed for control and eradication strategies including more precise and faster diagnosis and outbreak epidemiology data (SANCHEZ-VISCAÍNO, 1981; NIX et al., 2006; GALLARDO et al., 2009). Currently, HAD and immunofluorescence (IF) are considered the standard diagnosis methods determined by the World Animal Health Organization (Office International des Epizooties OIE)(LEÓN et al., 2013; www.oie.int, last visit: 07/08 2015).

In Brazil, ASF was eradicated in 1984 after six years of intense effort, determination, and imposed significant economic and social costs. The ASF outbreak index case (OIC) occurred in the city of Paracambi, state of Rio de Janeiro, where the disease was controlled (LYRA, 2006). However, pork meat commerce favored the propagation of the virus across other municipalities and states, especially in the south and southeast of the country (LYRA; FREITAS, 2015). In May 1978, pig tissue samples from Brazilian ASF outbreaks were sent to the Plum Island Animal Disease Center (PIADC) for diagnosis. At the PIADC, experimental infection of healthy pigs with the Brazilian strain induced a low-virulence form of the ASF with low mortality (MEBUS et al., 1978; MEBUS.; DARDIRI, 1979; MEBUS; SCHLAFER, 1982). These results corroborated the information on low mortality in Brazilian herds affected by ASF (LYRA, 1980). During the eradication campaign, epidemiological vigilance forms (FORMs) were filled with relevant information about herd conditions including number of infected animals, animals with clinical signs of disease, dead animals, vaccinations, and number of animals added or removed from the herd (LYRA; FREITAS; 2015).

Here, we have reviewed studies on the molecular aspects of Brazilian isolates from 1978 (WESLEY; PAN, 1981; 
TALAVERA et al., 1981; NIX et al., 2006) and 1979 (BASTOS et al., 2003; VILLIER et al., 1979). Results obtained from restriction fragment analysis, cloning and gene sequencing display the genotypic variation of viral samples. Viral genotyping based on sequences of the 3 ' region of the $p 72$ gene included genotype I samples, suggesting an European origin for the virus that infected Brazilian herds (DIXON; WILKISON, 1988; BASTOS et al., 2003; NIX et al., 2006).

In parallel, to corroborate the findings by MEBUS et al., $(1978,1979)$, a survey was conducted including FORMs from herds in better sanitary conditions that had at least one case of the disease as detected by HAD and/or IF (LYRA; FREITAS, 2015). The study analyzed 283 FORMs completed during the emergency phase of the program. The FORMs, gathered from outbreaks in the state of Parana, allowed the comparison of laboratory exams, clinical conditions, and mortality rates.

At the laboratory for ASF diagnosis (LASFD), tissue samples from animals with suspected ASFV infection were submitted to HAD and IF. The HAD technique relies on the ability that infected leukocytes have to elicit the adsorption of erythrocytes to the cellular membrane. Briefly, suspensions of animal tissue (tonsils, lymph nodes, spleen and liver) are placed on leukocyte cultures. Between 24 and $72 \mathrm{~h}$ later, a suspension of swine erythrocytes is added to the culture. Presence of the virus is determined by the occurrence of erythrocyte adsorption to infected leukocytes. IF detects viral antigens in infected cells and can be direct - when diagnosis is conducted directly on animal tissue - or indirect - when diagnosis is conducted on slides containing cultures of cells infected by animal tissue (LYRA; FREITAS, 2015).

At the PIADC, seven spleen samples and an entire lymph node were collected from eight pigs with clinical signs of ASF from Brazilian outbreaks. These samples were initially tested by direct IF followed by HAD analysis. Suspensions of the Brazilian samples were injected in nine healthy animal in an attempt to reproduce the disease under an experimental setting (MEBUS et al., 1978; MEBUS; DARDIRI, 1979; LYRA, 2006). The disease in Brazil, much like in other non-African countries, follows a less aggressive course and lower mortality rates suggestive of viruses with low to moderate virulence (LYRA, 1980). Thanks to European and American support (LYRA, 2006), some of the Brazilian samples were the subject of molecular, antigenic and pathogenic evaluations, and the virus was classified as having low pathogenicity (MALOGOLOVKIN et al., 2015).

In 1981, the Commission of the European Communities (CEC) and by the Food and Agriculture Organization (FAO) of the United Nations organized the CEC/FAO Expert Consultation in Africa Swine Fever Research Seminar in Sardinia, Italy. The published proceedings reported the works presented during the meeting, with emphasis on studies related to the epidemiology of ASF outbreaks. Several works also focused on antigenic aspects of the ASFV, and the obstacles to vaccine development. The studies on disease variability indicated the heterogeneity of viral populations in different ASF outbreaks, and the need for methods that could provide details of this variation, improve diagnosis and, consequently, epidemiological surveys.

Restriction analysis of DNA, or Restriction mapping, provided data about genetic variation among several field samples, including ASFV isolates from Brazil. Brazilian samples were characterized as having low virulence potential and were applied as references in subsequent viral antigenicity assays (SANCHEZ-VISCAÍNO et al., 1981).

Restriction mapping relies on the property of some bacterial restriction enzymes, endonucleases, to cleave DNA in specific points, forming fragments of a defined size. Cleaving takes place on DNA segments with a determined sequence of nucleotides. Each type of endonuclease identifies a single series of nucleotides, in general composed of four or six bps called restriction sites. Thus, each restriction enzyme generates a set of standard fragments for any given genome (http://www.nature. com/scitable/definition/restriction-mapping-283). WESLEY and PAN (1981) presented a comparative study of restriction fragments obtained from five ASFV field samples identified as Lisbon 60, Vero viral strain or V-6, HAITI (1979), BRAZIL (1978) and Dominican Republic or DR (1978). These samples were propagated in Vero cells and then submitted to restriction mapping. Brazil, Haiti and DR samples were submitted to one passage and Lisbon 60 to six passages in live pigs before adaptation to the cell lineage. The V-6 strain, which has the same origin as the Lisbon 60 strain, went through 89 in vitro passages. After adaptation to Vero cells, all samples were purified by plating for homogenization of viral populations. Viral DNA was extracted and purified in a sucrose gradient. Cleavage with the Sma1 enzyme produced 12 fragments with a same pattern for each strain. The electrophoretic profile of fragments from V-6, Lisbon 60, Haiti, and Brazil strains displayed $92 \%$ homology. Homology in DR fell to $75 \%$. Due to the high homology of the bands, cleavage with a second enzyme, EcoR-1 was performed to allow for better differentiation of DNA molecules from the isolates. EcoR-1 cleaved DNA into 29 or more fragments resulting in an electrophoretic profile that resembled the one produced by Sma1 and, as a result, five samples co-migrated. However, EcoR-1 digestion allowed the definition of the ASFV restriction pattern: a series of bands of approximately 1.7 and $3.0 \mathrm{kbs}$ and intense bands representing two DNA fragments of 7 and $11 \mathrm{kbs}$. All five isolates could be easily identified by the EcoR-1 restriction pattern. In parallel, the existence of standard fragments with different lengths after Sma1 and EcoR-1 restriction defined specific patterns for each isolate. The differences probably emerged from deletions or rearrangement of the viral genome.

To determine the ASFV structure and organization, Talavera et al. (1981) also included Brazilian samples in their assays. Six ASFV samples were selected: an isolate from the 
spleen of an animal infected in Badajoz, Spain, in 1971 and cloned in swine macrophages; the same isolate from Badajoz after 60 passages in macrophage cultures; the same isolate from Badajoz adapted to Vero cells; two independent Brazilian strains named Brazil 1 and Brazil 2; and a DR strain. Viral samples were adapted to Vero cells. Viral DNA was marked in vivo with radioactive phosphorus (P32), extracted from the cells and cleaved with 22 restriction enzymes that generated fragments of different sizes. Cleavage with Sal-1 generated 13 fragments, and with EcoR-1 generated 27 fragments. EcoR-1 restriction fragments were cloned in lambda vectors WES and $\mathrm{B}$ forming a collection of lambda clones with different ASFV fragments. Both Sal-1 and EcoR-1 fragments were hybridized with viral DNA marked with P32. Homology analysis revealed that Badajoz samples were grouped in a single Spanish group, whereas Brazilian and DR samples were grouped as American. American samples exhibited an identical Sal-1 restriction pattern. Although the two groups of Spanish and American samples displayed intrinsic differences, deletions in the terminal regions of the viral DNA suggest a degree of relationship between Spanish and American samples, as well as those adapted to Vero cells.

The development of polymerase chain reaction (PCR)-based sequencing methods facilitated the study of viral genomes. The reaction amplifies specific genomic sequences which, when compared to a standard sequence, allow the identification and epidemiological correlation of viral strains. The ASFV monitoring system introduced in a region with no previous history of the disease resulted from the efficacy of this technique in the investigation of ASFV molecular and epidemiological patterns. The total or partial analysis of genes that code for capsid and/or antigenic proteins allow for epidemiological determinations and viral monitoring (OIE, 2016).

In 2007, PCR amplification combined with DNA sequencing shed light on an outbreak that took place in Georgia, in the Caucasus region. The comparison of viral genomic sequences from outbreak isolates to pre-established ASFV standards was crucial for the determination of viral origins in different outbreaks. In the case of the Georgia outbreak, four gene regions were compared: part of the $B 464 \mathrm{~L}$ gene; the $E 183 \mathrm{~L}$ and $C P 204 \mathrm{~L}$ genes; and the variable region of the $B 602 \mathrm{~L}$ gene (ROWLANDS et al., 2008; CHAPMAN et al., 2011).

When used in combination with restriction fragment length polymorphism (RFLP), PCR increased chances of discriminating sample genotypes (BOTSTEIN et al., 1980). The joint use of PCR and RFLP revealed a high level of variability in genes associated with the virulence of African and non-African ASFV isolates. Restriction mapping of viral genome followed by DNA sequencing revealed a preserved central region of $125 \mathrm{kbps}$, and highly variable regions in the 3 ' and 5' termini with 40 and $15 \mathrm{kbps}$, respectively. Currently, ASFV genotyping is based on the analysis of three independent segments located in the central preserved region: the partial sequence of the $B 646 \mathrm{~L}$ gene region that codes for the C-terminal of the p72 capsid protein; the entire sequence of the $E 183 \mathrm{~L}$ gene that codes for the p54 protein; and the sequence of a central variable region within the $B 602 L$ gene characterized by the presence of tandem repeats (Fig. 2). The $E 183 \mathrm{~L}$ sequence is particularly useful when genotype 1 viruses are predominant. The $B 602 \mathrm{~L}$ sequence distinguishes genetically similar viral strains.

Since the year 2000, Brazilian samples isolated in 1978 and 1979 were included in several analyses of genetic variability comparing ASFV strains isolated in Africa, Europe, the Caribbean and South America. BASTOS et al. (2003) developed a method for the sequencing of a PCR product of $478 \mathrm{bp}$ corresponding to the 3 ' region of the $B 646 L$ gene (Fig. 2). The method allowed the identification of 22 genotypes upon analysis of 55 viral samples which included the main ASFV strains previously identified by RFLP. Results confirmed RFLP genotyping, and included the Brazilian isolate from 1979 among genotype I viruses (Genbank accession number Af302809). In 2006, Nix and collaborators compared the genomes of ASFV isolates obtained in 40 years of epidemiological and phylogenetic studies. The comparison relied on the analysis of TRS rich variable regions. The analysis of PCR product sizes focused on four different genomic regions: $B 602 L$ and KP86R genes and intergenic regions J286L and $\mathrm{BtSi}$. Forty-three genetically similar viral isolates from Europe, the Caribbean, and West and Central Africa were divided into subgroups according to sequence and number of four-aminoacid TRS. The TRS pattern in these regions yielded 13 subtypes of genotype I, which included Brazilian samples collected in 1978 and in 1979. GALLARDO et al. (2009) sequenced the genes coding for p54, p72 and p602L proteins. Based on the complete p54 sequence from $67 \mathrm{ASFV}$ isolates (European, American, West and East African), the authors found that European isolates classified as genotype I could be segregated into four main subtypes that serve as tool for molecular epidemiology and genotyping studies.

The comparative study of ASFV genotypes and serotypes led by Malogolovkin, in Russia, include an ASFV sample from the 1979 outbreak in Brazil (genebank KJ526367). Phylogenetic analysis of the $\mathrm{p} 72$ protein and serological evaluation of this Brazilian sample confirmed previous results and grouped it, along with European and American samples, in genotype 1 and serotype 4 . The presence of serotypes 1, 2 and 4 within a single genotypic clade, genotype 1, provided evidence of the heterogeneity among samples (MALOGOLOVKIN et al., 2015).

Low mortality rates, delayed appearance of clinical symptoms, the recovery of infected animals and the development of antibodies reflect the low virulence of Brazilian strains (MEBUS et al., 1978, LYRA, 1980). From an epidemiological point of view, this relatively mild disease course reduces the chance of correct diagnosis and may increase viral propagation. The high mortality of pigs observed during the outbreak index in Paracambi initially suggested the involvement of a highly virulent strain. 
However, the bad sanitary conditions of the herd in Paracambi may have favored the concomitant incidence of other infections and infestations that may have contributed to the outcome (LYRA, 2006). At the PIADC, experimental inoculation of healthy pigs with the Brazilian ASFV resulted in a mild form of ASF. However, even before the conclusion of the inoculation experiment, samples from the Brazilian outbreak were tested by HAD, Fluorescent antibody test (FAT) and Immunoelectr oosmophoresis (IEOP) at the PIADC. According to standard procedures, the FAT technique is conducted over frozen tissue. When applied to the Brazilian samples, these tests yielded negative results for ASFV, which could be due to the low viral load in the sample. The HAD test yielded a weak positive result. Similarly, only 8 out of 18 samples from infected animals from the state of Parana were diagnosed with a single passage, another eight required two passages, and two samples required a third passage (FREITAS; LYRA, 2016).

At the PIADC, nine crossbred animals inoculated with the Brazilian strain developed ASF. The first symptoms included fever between $40^{\circ} \mathrm{C}\left(104^{\circ} \mathrm{F}\right)$ and $42^{\circ} \mathrm{C}\left(108^{\circ} \mathrm{F}\right)$, which started in the second day post-inoculation (PI), and continued until the animals died. In animals that survived the disease, the fever stopped between days 18 and 20 PI. Animals were recumbent and not active, but not anorexic. Some developed diarrhea. One animal died on day 11 and four died between days 14 and 24 PI.

Laboratory animals, maintained under controlled conditions, and herd animals may have differences in their immunological systems and health conditions. Nevertheless, similarities in the development of ASF may reflect the virulence of the infecting strain. Among the FORMs from each of the 18 Parana herds with at least one infected animal detected by HAD, one had similar characteristics to those described by MEBUS et al. (1978). FORM 023017 provides the records from a crossbred herd of pigs from the city of Santa Helena that had been previously vaccinated against classic swine fever. The animals were raised for industrial meat production. The herd included 146 animals, among which 30 were piglets with less than 3 months of age, 13 were at the grow stage, 59 were at the finish stage, 40 were sows, and there were 4 boars. Two animals at the grow stage started developing clinical signs of ASF on June 15, 1978. They had fever $\left(41.5^{\circ} \mathrm{C}\right)$, motor difficulties, convulsions, purple spots on ears and belly regions and tachycardia. The first death was recorded 12 days after the initial symptoms. The ASFV was detected by FAT and isolated by HAD in the first passage. The prolonged time before the first death resembles the disease characteristics described by MEBUS et al. (1978), and reflects the activity of a strain with lower virulence. The low virulence of Brazilian strains had already been suggested based on mortality rates and clinical symptoms (LYRA, 1980). Relevant data about ASFV-positive Parana herds include 1,060 infected animals, 91 with overt signs of the disease and 58 deaths. Prevailing disease symptoms in the FORMs were fever, anorexia, recumbent animals, redness and/or cyanotic skin, diarrhea, skin hemorrhage, tremor, weakness of the hind legs. Mortality rates in June (10\%) and July $(0.16 \%)$ further suggest the occurrence of a low-virulence strain (LYRA; FREITAS, 2015).

The genomic DNA of ASFV strains with no or low virulence is usually smaller $(170 \mathrm{kbps})$ than the DNA of virulent viruses (>180 kbps) (CHAPMAN et al., 2008; DIXON et al., 2013). Comparison between non-virulent and virulent genotype 1 strains indicated that non-virulent strain DNA had deletions of 1 to $7 \mathrm{kbps}$ in the ITR regions (BLASCO et al., 1989). However, CHAPMAN et al. (2008) compared the non-virulent strains ASFV-BA71V and ASFV-OURT88/3 to the virulent one ASFV-Benin97/1. The authors showed that, in former strains, a $10 \mathrm{kbps}$ sequence was deleted from MGF360, which includes six genes and is located $20 \mathrm{kbps}$ from the 5 ' terminus. The same authors indicated that virulent strains ASFV-E75 and ASFV-Benin97/1 have each a unique gene among the 16 MGF genes: $M G F 360-1 L$ in ASFV-Benin97/1 and MGF360-20R in ASFV-E75. However, both isolates have and additional MGF- $6 L$ gene which is not present in non-virulent isolates.

Because no anti-ASFV vaccines exist, a number of studies have focused on the immune response of infected animals. SANCHEZ-VISCAÍNO et al. (1981) used the 1978 Brazilian isolates and the DR strain as low virulence standards and Lisbon 60 as the high virulence standard in the assessment of viremia and duration of ASF triggered by high and low virulent strains. The authors monitored the clinical signs of pathology, viremia, antibody development, blood parameters, among other markers in adult animals and piglets. While all adult animals inoculated with the non-virulent strains survived the entire 15 day observation period, all animals inoculated with the Portuguese strain died or had to be euthanized within nine days. Piglets died within four days, regardless of the strain used. These data show that in addition to strain virulence, animal age also represents a key factor in disease development. Consistently, MEBUS; SCHLAFER (1982) suggested that physiological parameters, including those determined by age, gender, and the immune system, as well as sanitary conditions interfere with the development of ASFV infection.

The ASF poses a threat to pig herds in Europe warranting an increase in the studies about the virus and the development of disease control strategies. The ASF is endemic to sub-Saharan Africa and Sardinia. Since 2007, outbreaks have also occurred in the Caucasus region, Eastern Europe and Baltic countries. Current gaps in our knowledge of the virus may be partly corrected by investigations of past outbreaks. Brazil eradicated the ASF in 1984, after an intensive program to fight all possible disease outbreaks in several states. The ASFV arrived in Brazil in the left over food during flights from the Iberian Peninsula (LYRA, 2006). Currently, the ease and speed with which people move and exchange goods intensify the risk of viral propagation from country to country (COSTARD et al., 2009). The ASF, when caused by low-virulence strains, can increase 
the problem because of hidden viral reservoirs, further reinforcing the need for safety and preventive measures in virus-free countries. Finally, the problem is further compounded by the lack of vaccines and other immunological resources.

\section{ACKNOLWLEDGEMENTS}

We thank Francisco Sérgio Pereira Freitas - "Chico Lá” for revising the original Portuguese text.

| | | | | | | | | | | | | | | | | | | | | | | | | | | | | | | | | | | | | | | | | | | | | | | | | | | | | | | | | | | | | | | | | | | | | | | | | | | | | | | | | | | | | | | | | | | | | | | | | | | | | | | | | | | | | | | | | | | | | | | | | | | | | | | | | | | | | | | | | | | | | | | | | | | | | | | | | | | | | | | | | | | | | | | | | | | | | | | | | | | | | | | | | | | | | | | | | | | | | | | | | | | | | | | | | | | | | | | | | | | REFERENCES

AFONSO, C.L.; PICCONE, M.E.; ZAFFUTO, K.M.; NEILAN, J.; Kutish, G.F Lu, Z.; Balinsky, C.A.; Gibb, T.R.; Bean, T.J.; Zsak, L.; Rock, D.L. African Swine Fever Virus Multigene Family 360 and 530 Genes Affect Host Interferon Response. Journal of Virology, v.78, n.4, p. 1858-1864, 2004.

ALCAMI, A; ANGULO, A.; LOPEZ-OTIN, C.; MUNOZ, M.; FREIJE, J.M.P.; CARRASCOSA, A.L.; VINUELA, E. amino acid sequence and structural properties of protein $\mathrm{p} 12$, an african swine fever virus attachment protein. Journal of Virology, v.66, n.6, p.3860-3868, 1992.

ANDRÉS, G.; MATEO, C.S.; VIÑUELA, E. Assembly of african swine fever virus: role of polyprotein pp220. Journal of Virology, p.2331-2341, v.71, n.3, 1997.

BASTO, A. P.; NIX, R.J.; BOINAS, F.; MENDES, S.; SILVA, M.J.; CARTAXEIRO, C.; PORTUGAL, R.S.; LEITÃO, A.; DIXON, L.K.; MARTINS, C. Kinetics of African swine fever virus infection in Ornithodoros erraticus ticks. Journal of General Virology, v.87, n.7, p. 1863-1871, 2006.

BASTOS, A.D.S.; PENRITH, M.-L.; CRUCIĖRE, C.; EDRICH, J.L.; HUTCHINGS, G.; ROGER, F.; COUACY-HYMANN, E., THOMSON, G.R. Genotyping field strains of African swine fever virus by partial p72 gene characterization. Archives of Virology, v. 148, n.4, p.693-706, 2003.

BLASCO, R; AGÜERO, M.;ALMENDRAL, J.M.;VIÑUELA, E. Variable and constant regions in African swine fever virus DNA. Virology, v. 168, p.330-338, 1989.

BOTSTEIN, D.; WHITE, R.L.; SKOLNICK, M.; DAVIS, R.W. Construction of a genetic linkage map in man using restriction fragment length polymorphisms. American Journal of Human Genetic, v.32, p.314-331, 1980.

BURRAGE, T.G.; LU, Z.; NEILAN, J.G.; ROCK, D.L; ZSAK, L. African swine fever virus multigene family 360 genes affect virus replication and generalization of infection in ornithodoros porcinus ticks. Journal of Virology, v.78, n.5, p.2445-2453, 2004.

CARRILLO, C.; BORCA, M.V.; AFONSO, C.L.; ONISK, D.V.; ROCK, D.L. Long-Term Persistent Infection of Swine Monocytes/ Macrophages with African Swine Fever Virus. Journal of Virology, v.68, n.1, p.580-583, 1994.

CHAPMAN, D.A.; TCHEREPANOV, V.; UPTON, C.; DIXON, L.K. Comparison of the genome sequences of non-pathogenic and pathogenic African swine fever virus isolates. Journal of General Virology, v.89, n.2, p.397-408, 2008.
CHAPMAN, D.A.G.; DARBY, A.C.; DA SILVA, M.; UPTON, C; RADFORD, A.D.; DIXON, L.K. Genomic analysis of highly virulent Georgia $2007 / 1$ isolate of African swine fever virus. Emerging Infectious Diseases, v.17, p.599-605, 2011.

COSTARD, S.; WIELAND, B.; GLANVILLE, W.; JORI, F.; ROWLANDS, R.; VOSLOO, W.; ROGER, F.; PFEIFFER, D.U.; DIXON, L.K. African swine fever: how can global spread be prevented? Philosophical Transactions of the Royal Society B, v.364; p.2683-2696, 2009.

DIXON, L.K.; WILKINSON, P.J. Genetic diversity of african swine fever virus isolates from soft ticks (Ornithodoros moubata) inhabiting warthog burrows in Zambia. Journal of General Virology, v.69, p.2981-2993, 1988.

DIXON, L.K.; CHAPMAN, D.A.G.; NETHERTON, C.L.; UPTON, C. African swine fever virus replication and genomics. Virus Research, v.173, n. 1, p.3-14, 2013.

ENJUANES, L.; CARRASCOSA, A.L.; MORENO, M.A.; VIÑUELA, E. Titration of African swine fever virus. Journal of General Virology, v.32, p.471-477, 1976.

FREITAS, T.R.P.; SOUZA, A.C.; ESTEVES, E.G.; LYRA, T.M.P. Comparação dos métodos virológicos aplicados no diagnóstico da peste suína africana no Brasil, 1978. Revista Brasileira de Medicina Veterinária, v.37, n.3, p.255-263, 2015.

GALLARDO, C.; MWAENGO, D.M.; MACHARIA, J.M.; ARIAS, M.; TARACHA, E.A.; SOLER, A.; OKOTH, E., MARTIN, E.; KASITI, J.; Bishop, R.P. Enhanced discrimination of African swine fever virus isolates through nucleotide sequencing of the $p 54, p 72$, and pB602L (CVR) genes. Virus Genes, v.38, p.85-95, 2009.

GALLARDO, C.; OKOTH, E.; PELAYO, V.; ANCHUELO, R.; MARTI'N, E.; SIMON, A.; LLORENTE, A.; NIETO, R.; SOLER, A.; MARTIN, R.; ARIAS, M.; BISHOP, R.P. African swine fever viruses with two different genotypes, both of which occur in domestic pigs, are associated with ticks and adult warthogs, respectively, at a single geographical site. Journal of General Virology, v.92, n.2, p.432-444, 2011.

GUINAT,C.; GOGIN,A.; BLOME, S.; KEIL,G.; POLLIN, R., PFEIFFER; D.; DIXON, L. Transmission routes of African swine fever virus to domestic pigs: current knowledge and future research directions. Veterinary Record, v.178, p.262-267, 2016.

HAMDY, M; DARDIRI, A.H. Clinical and immunologic responses of pigs to African swine fever virus isolated from the Western Hemisphere. American Journal of Veterinary Research, v.45, n.4, p.711-714, 1984. 
HESS, W.R. African swine fever: reassessment. Advances in Veterinary Science and Comparative Medicine, v.25, p.39-69, 1981.

LEÓN, P.; BUSTOS, M.J.; CARRASCOSA, A.L. Laboratory methods to study African swine fever virus. Virus Research, v.173, n.1, p.168-179, 2013.

LYRA, T.M.P. A peste suína africana de baixa mortalidade. Boletim da Defesa Sanitária Animal, Brasília, número especial, p.50-59, 1980.

La erradicación de la peste porcina africana en el Brasil, 1978-1984. Revue Scientifique et Technique, Paris, v.25, n.1, p.93-103, 2006.

LYRA, T.M.P.; FREITAS, T.R.P. Epizootiology, laboratory and virulence analyses during the emergency phase of the African swine fever eradication program in Brazil in 1978: a historic account. Semina: Ciências Agrárias, v.36, n.4, p.2577-2592, 2015.

MCDANIEL. African Swine Fever. In: Leman, A.D. Disease of Swine. 5a. ed., pp. 237-245. The iowa state university Press, Ames, lowa, USA., 1981

MALOGOLOVKIN, A.; BURMAKINA, G.; TITOV, I.; SEREDA, A.; GOGIN, A. BARYSHNIKOVA, E.; KOLBASOV, D. Comparative Analysis of African Swine Fever Virus Genotypes and Serogroups. Emerging Infectious Diseases, v.21, n.2, p.312-315, 2015

MEBUS, C.A.; DARDIRI, A.H. Additional characteristic of disease caused by African swine fever viruses isolated from Brazil and the Dominican Republic. In: Annual Meeting of US Animal Health Association, 83, 1979, Buffalo. Proceedings... Buffalo: USAHA, 1979. p.227-239.

MEBUS, C.A.; DARDIRI, A.H.; HAMDY, F.M. Some characteristics of African swine fever viruses isolated in Brazil and Dominican Republic. In: Annual Meeting of US Animal Health Association, 82, 1978, Buffalo. Proceedings... Buffalo: USAHA, 1978. p.232-236.

MEBUS, C.A.; MAC VICAR, J.W.; DARDIRI, A.H. Comparison of the pathology of high and low virulence African swine fever virus infection In: CEC/FAO Expert Consultation in Africa Swine fever Research Seminar, 1981, Sardinia. Proceedings... Sardinia: Ed. P.J. Wilkinson, 1981. p.183-194.

MEBUS, C.A.; SCHLAFER, D.H. African swine fever in Americas: a changing disease. In: First International Conference on the impact of viral disease on the development of latin America and Caribbean region, 1982, Rio de Janeiro. Proceedings... Rio de Janeiro: Ed. Instituto Oswaldo Cruz, 1982. v.1, p.198-202.

NEILAN, J.G.; ZSAK, L.;LU, Z.; KUTISH, G.F.; AFONSO, C.L.; ROCK $D$.L. Novel swine virulence determinant in the left variable region of the African swine fever virus genome. Journal of Virology, Birmingham, v.76, n.7, p.3095-3104, 2002.
NIX, R.J.; GALLARDO, C.; HUTCHINGS, G.; BLANCO, E.; DIXON, L.K. Molecular epidemiology of African swine fever virus studied by analysis of four variable genome regions. Archive of Virology, New York, v.151, n. 12, p.2475-2494, 2006.

OIE, Manual of diagnostic tests and vaccines for terrestrial animals. African swine fever. Section 2.8 Suidae, Chapter 2.8.1, p. 1067-1081, 2016.

PAN, I.C.; WHYARD, T.C.; HESS, W.R.; YUASA, N.; SHIMIZU, M. Epitopic diversity of African swine fever virus. Virus Research, v.9, n.2-3, p.93-106, 1988.

ROUILLER, I.; BROOKES, S.M.; HYATT, A.D.; WINDSOR, M.; WILEMAN, T. African swine fever virus is wrapped by the endoplasmic reticulum. Journal of Virology, v.72, n.3, p.2373-2387, 1998.

SALAS, M.L.; ANDRÉS, G. African swine fever virus morphogenesis. Virus Research, v.173, p.29-41, 2013.

SÁNCHEZ-VIZCAÍNO, J.M; MEBUS, C.A; MCVICAR, J.W.; VALERO, F. Studies on humoral and cell mediated immunity in pigs ans piglets infected with different field isolates of African swine fever virus. . In: CEC/FAO Expert Consultation in Africa Swine Fever Research Seminar 1981, Sardinia. Proceedings... Ed. P. J. Wilkinson, p.195-205.

TALAVERA, A.; ALMENDRAL, J.W.; LEY, V.; VIÑUELA, E. Cloning and mapping of restriction fragments from african swine fever virus DNA. In: CEC/FAO Expert Consultation in Africa Swine Fever Research Seminar 1981, Sardinia. Proceedings... Ed. P. J. Wilkinson, p.254-262.

THOMSON, G.; GAINARU, M.; LEWIS, A.; BIGGS, H.; NEVILL, E.; VAN DER PYPEKAMP, H.; GERBES, L.; ESTERHUYSEN, J.; BENGIS, R.; BEZUIDENHOUT, D.; CONDY, J. The relationship between ASFV, the warthog and Ornithodoros species in southern Africa, In: CEC/ FAO Expert Consultation in Africa Swine Fever Research Seminar 1981, Sardinia. Proceedings... Ed. P. J. Wilkinson, p. 85-100.

TULMAN, E.R.; ROCK, D.L. Novel virulence and host range genes of African swine fever virus. Current Opinion in Microbiology, v.4, n.4, p.456-461, 2001.

VILLIERS, E.P.; GALLARDO, C.; ARIAS, M.; SILVA, M.; UPTON, C.; MARTIN, R.; BISHOP, R.P. Phylogenomic analysis of 11 complete African swine fever virus genome sequences. Virology, v.400, n. 1, p.128-136, 2010.

WESLEY, R.D.; PAN, I.C. Differentiation of vero cell-adapted African swine fever virus isolates by restriction endonuclease analysis. In: CEC/FAO Expert Consultation in Africa Swine Fever Research Seminar 1981, Sardinia. Proceedings... Ed. P. J. Wilkinson, p.240-253.

YANEZ, R.J.; RODRIGUEZ, J.M.; NOGAL, M.L.; YUSTE, L.; ENRIQUEZ, C.; RODRIGUEZ, J.; VINUELA, E Analysis of the completenucleotide sequence of African swine fever virus. Virology, v.208, n. 1, p.249-278, 1995. 